\title{
Two distinct calcium pools in the endoplasmic reticulum of HEK293T cells
}

\section{Francisco J. AULESTIA*, Pedro C. REDONDO ${ }^{\dagger}$, Arancha RODRÍGUEZ-GARCÍA*, Juan A. ROSADO $^{\dagger}$, Ginés M. SALIDO ${ }^{\dagger}$, Maria Teresa ALONSO* ${ }^{*}$ and JAVIER-GARCÍA-SANCHO ${ }^{* 1}$}

*Instituto de Biología y Genética Molecular (IBGM), Universidad de Valladolid y Consejo Superior de Investigaciones Científicas (CSIC), c/ Sanz y Forés s/n, 47003 Valladolid, Spain and ${ }^{\dagger}$ Cell Physiology Research Group, Department of Physiology, Universidad de Extremadura, Av. de la Universidad s/n, 10071 Cáceres, Spain

Short title: Two distinct ER calcium pools in HEK cells

${ }^{1}$ To whom correspondence should be addressed at: Dr. J. García-Sancho, IBGM, c/Sanz y Forés s/n, 47003-Valladolid, Spain. Phone: 34-983-423084; Fax: 34-983-421800; e-mail: jgsancho@ibgm.uva.es

\section{SYNOPSIS}

Agonist-sensitive intracellular $\mathrm{Ca}^{2+}$ stores may be heterogeneous and exhibit distinct functional features. We have studied the properties of the intracellular $\mathrm{Ca}^{2+}$ stores using targeted aequorins for selective measurements in different subcellular compartments. Both, HEK293T and HeLa cells accumulated $\mathrm{Ca}^{2+}$ into the endoplasmic reticulum (ER) to near milimolar concentrations and the $\mathrm{IP}_{3^{-}}$ generating agonists carbachol and ATP were able to mobilize this $\mathrm{Ca}^{2+}$ pool. We find in HEK, but not in HeLa cells, a distinct agonist-releasable $\mathrm{Ca}^{2+}$ pool insensitive to the sarco-endoplasmic reticulum $\mathrm{Ca}^{2+}$ ATPase (SERCA) inhibitor, 2,5-di(tert-butyl)-1,4-benzohydroquinone (TBH). Thapsigargin and cyclopiazonic completely emptied this pool whereas lysosomal disruption or manoeuvres collapsing endomembrane $\mathrm{pH}$ gradients did not. Q-RT-PCR analysis showed that SERCA3d is 20 times more abundant in HEK than in HeLa cells. Importantly, we find that SERCA3 ATPase activity was not fully sensitive to TBH and that expression of SERCA3d in HeLa cells generated a TBH-resistant, agonistmobilizable compartment in the ER. These findings indicate that differential distribution of SERCA isoforms may originate heterogeneity of the $\mathrm{ER} \mathrm{Ca}^{2+}$ stores. The question of whether different stores may subserve diverse functions will require further research.

\section{KEYWORDS:}

Endoplasmic reticulum, Calcium, intracellular calcium stores, aequorin, calcium microdomains, SERCA, Sarco/endoplasmic Ca2+ ATPase

\section{ABBREVIATION FOOTNOTE:}

Abbreviations used are: GFP, green fluorescent protein; GA, chimeric GFP-AEQ fusion protein; ER, endoplasmic reticulum; SERCA, Sarco(endo)plasmic reticulum $\mathrm{Ca}^{2+}$ ATPase, $\left[\mathrm{Ca}^{2+}\right]_{\mathrm{C}}$, cytosolic free $\mathrm{Ca}^{2+}$ concentration; $\left[\mathrm{Ca}^{2+}\right]_{\mathrm{ER}}, \mathrm{Ca}^{2+}$ concentration inside ER; TBH, 2,5-di-tert-butylbenzohydroquinone; TG, thapsigargin; DTS, dense tubular system; GPN, glycylphenylalanine-2naphthylamide; AEQ, aequorin; erGA, ER-targeted GA; $\mathrm{IP}_{3}$, inositol 1,4,5, trisphosphate; $\mathrm{CCh}$, carbachol. 


\section{INTRODUCTION}

Changes of the cytosolic free $\mathrm{Ca}^{2+}$ concentration $\left(\left[\mathrm{Ca}^{2+}\right]_{\mathrm{C}}\right)^{3}$ are key activation signals for many physiological processes [1]. In non-excitable cells, these $\left[\mathrm{Ca}^{2+}\right]_{\mathrm{C}}$ signals are usually generated by $\mathrm{Ca}^{2+}$ release from the intracellular $\mathrm{Ca}^{2+}$ stores, which can be triggered by a variety of intracellular messengers. Most of the second messenger-mobilizable $\mathrm{Ca}^{2+}$ seems to be stored into the endoplasmic reticulum (ER), but other organelles such as the Golgi network [2] the lysosomes [3-5]or the secretory granules [6-8] may also release $\mathrm{Ca}^{2+}$ to the cytosol and contribute to $\mathrm{Ca}^{2+}$ signaling.

Functional heterogeneity of the intracellular $\mathrm{Ca}^{2+}$ stores was first proposed in platelets on the basis of the existence of two different organellar-type $\mathrm{Ca}^{2+}$ ATPases with different molecular weights, phosphorylation patterns and sensitivity to the sarcoendoplasmic reticulum $\mathrm{Ca}^{2+}$-ATPase (SERCA) inhibitor 2,5-di(tert-butyl)-1,4-benzohydroquinone (TBH) [9]. These two platelet SERCA isoforms, which are also expressed in lymphoid cells, resulted to be SERCA2b and SERCA3 [10]. A contemporary functional study in platelets [11] also revealed the existence of two $\mathrm{Ca}^{2+}$ stores able to accumulate $\mathrm{Ca}^{2+}$ with differential sensitivity to inhibitors; the $\mathrm{Ca}^{2+}$ pumping activity expressed in one of the stores was fully inhibited by $10 \mathrm{nM}$ thapsigargin (TG) and was not sensitive to TBH while the one expressed in the other store was less sensitive to TG but blocked by $10 \mu \mathrm{M} \mathrm{TBH}$. Further investigation on this topic has shown that the TBH-sensitive $\mathrm{Ca}^{2+}$ store is probably an acidic subcellular compartment, such as the lysosome, as that it is emptied by the lysosome-disrupting peptide glycylphenylalanine-2-naphthylamide (GPN), by the vacuolar $\mathrm{H}^{+}$-ATPase inhibitor bafilomycin or by the $\mathrm{H}^{+} / \mathrm{K}^{+}$ionophore nigericin. The TBH-sensitive store contains about half as much $\mathrm{Ca}^{2+}$ as the TBH-insensitive [12] and is mobilizable by NAADP [13]. The TBH-insensitive store of platelets would coincide with the dense tubular system (DTS, the equivalent to the ER in platelets) and would be mobilizable through inositol-trisphosphate $\left(\mathrm{IP}_{3}\right)$ receptors [13]. Thrombin releases $\mathrm{Ca}^{2+}$ from both stores while ADP or vasopressin release $\mathrm{Ca}^{2+}$ only from DTS [14]. In platelets, it has been proposed that many of the differences in behavior are due to the differential expression of SERCA isoforms in the different stores, a TBH-sensitive SERCA3 in the acidic stores and a TBH-insensitive SERCA2b in DTS $[13,15]$.

The presence of a TBH-insensitive SERCA in smooth muscle, skeletal muscle and heart, which express mainly SERCA1 and SERCA2 isoforms [16], was also proposed in the platelets studies [10]. However, later studies have generally reported that SERCA1, 2 and 3 are all similarly sensitive to $\mathrm{TBH}$, with $\mathrm{IC}_{50}$ in the micromolar range [17-20]. The origin of these contradictory observations is unclear. There may be differences in behavior between different cell types or between isoforms within the same SERCA family. For SERCA3, for example, six different isoforms, a to f, have been described [19].

Inhomogeneities of the intracellular $\mathrm{Ca}^{2+}$ stores have also been reported in other cell types. In some cases the differences may be due to the contribution of other organelles such as the Golgi network $[2,21]$, the lysosomes [3-5] or the secretory granules[6-8] to $\mathrm{Ca}^{2+}$ homeostasis.

Inhomogeneities in the $\mathrm{ER} \mathrm{Ca}^{2+}$ store itself have also been proposed on the basis of different $\mathrm{Ca}^{2+}$ contents or sensitivity to TG [22], but the mechanisms involved have not been investigated in detail.

In the present paper we analyze the homogeneity of intracellular $\mathrm{Ca}^{2+}$ stores in HEK293T and HeLa cells and their response to mobilizing agonists. Using ER-targeted aequorins to study the different $\mathrm{Ca}^{2+}$ stores, we have been able to identify a TBH-resistant $\mathrm{Ca}^{2+}$ pool in the ER of HEK cells, which can be mobilized by $\mathrm{IP}_{3}$-producing agonists. On the contrary, the whole $\mathrm{Ca}^{2+}$ pool stored in the ER of HeLa cells is homogeneous and can be emptied by TBH.

\section{EXPERIMENTAL PROCEDURES}

\section{Cell culture and gene transfection}

HEK293T (ATCC CRL-11268) and HeLa (CCL-2) cells were maintained in DMEM (Invitrogen) supplemented with $10 \%(\mathrm{v} / \mathrm{v})$ foetal bovine serum, $2 \mathrm{mM} \mathrm{L}$-glutamine, $100 \mu \mathrm{g} / \mathrm{ml} \mathrm{streptomycin} \mathrm{and}$ $100 \mathrm{U} / \mathrm{ml}$ penicillin at $37^{\circ} \mathrm{C}$, under an air/ $5 \% \mathrm{CO}_{2}$ mixture. A stable HEK293 clone expressing erGFP-aequorin (erGA) was generated by transfecting the erGA cDNA and selecting the neomycin 
resistant clones in $800 \mu \mathrm{g} / \mathrm{ml} \mathrm{G}-418$ (Invitrogen) by limited dilution. The clone was routinely cultured in $100 \mu \mathrm{g} / \mathrm{ml} \mathrm{G}-418$.For aequorin measurements, cells were seeded on $12 \mathrm{~mm}$ diameter poly-L-lysinecoated coverslips at $7 \times 10^{4}$ cells/coverslip. HeLa cells were transfected with $0.1 \mu \mathrm{g}$ erGA cDNA using lipofectamine 2000 (Invitrogen). The human SERCA3d cDNA (kindly provided by Dr. Jocelyne Enouf, Inserm, U 689, Paris) was cotransfected together with erGA at a 3:1 ratio.

\section{Measurements of cytosolic free $\mathrm{Ca}^{2+}$ concentration $\left(\left[\mathrm{Ca}^{2+}\right]_{\mathrm{C}}\right)$}

The procedure was as described previously [23,24]. Briefly, cells, attached to $12 \mathrm{~mm}$ diameter coverslips, were loaded with $4 \mu \mathrm{M}$ fura2-acetoxymethyl ester (fura-2/AM, Molecular Probes) for $1 \mathrm{~h}$ at room temperature in standard incubation medium of the following composition (in $\mathrm{mM}$ ): $\mathrm{NaCl}, 145$; $\mathrm{KCl}, 5 ; \mathrm{MgCl}_{2}, 1 ; \mathrm{CaCl}_{2}, 1$; glucose, 10; sodium-HEPES, 10, $\mathrm{pH}, 7.4$. The cell-coated coverslips were then mounted under a 20x Olympus PlanApoUV objective in a Nikon Diaphot microscope and washed with fresh medium. Test solutions were applied by continuous perfusion at $2-3 \mathrm{ml} / \mathrm{min}$. For fluorescence measurements, cells were alternately epi-illuminated at 340 and $380 \mathrm{~nm}$ and light emitted above 520-nm was recorded using a Hamamatsu Digital Camera C4742-98 handled by Simple PCI 6.6 Hamamatsu software. Consecutive frames obtained at 340 and $380 \mathrm{~nm}$ excitation were ratioed pixel by pixel using imageJ software and calibrated in $\left[\mathrm{Ca}^{2+}\right]_{\mathrm{C}}$ by comparison with fura-2 standards [23].

\section{Measurements of the free $\mathrm{Ca}^{2+}$ concentration inside the ER $\left(\left[\mathrm{Ca}^{2+}\right]_{\mathrm{ER}}\right)$}

The GFP-aequorin (GA) fusion protein targeted to the ER (erGA) containing the mutated, low $\mathrm{Ca}^{2+}$ affinity, aequorin was used [25]. Cells expressing erGA were incubated for $1 \mathrm{~h}$ at room temperature with $1 \mu \mathrm{M}$ of coelenterazine, either native or $\mathrm{n}$, in a standard $\mathrm{Ca}^{2+}$-free medium (same composition as the standard medium described above except that $\mathrm{CaCl}_{2}$ was omitted and $0.5 \mathrm{mM}$ EGTA was added) in order to reconstitute the aequorin [26]. When aequorin is reconstituted with coelenterazine $n$ the affinity for $\mathrm{Ca}^{2+}$ is still smaller and measurements up to the milimolar range are possible [26-28]. The reconstitution medium contained also $10 \mu \mathrm{M}$ of the SERCA inhibitor TBH in order to prevent refilling of the $\mathrm{Ca}^{2+}$ stores, which would lead to burning of the reconstituted aequorin. Finally, the cells were washed once with $\mathrm{Ca}^{2+}$-free medium and perfused as described in each case. Aequorin photoluminescence was measured as described previously in a luminometer constructed by Cairn Research Ltd [29], and calibrations in $\left[\mathrm{Ca}^{2+}\right]$ were done using the constant values published before [30]. All the measurements were performed at $22^{\circ} \mathrm{C}$.

\section{SERCA3 activity determination}

Determination of SERCA activity was perfortmed using an enzyme-coupled assay in samples purified by SERCA3 immunoprecipitation [31, 32]. Briefly, the cell suspension $\left(6 \times 10^{6}\right.$ cells $\left./ \mathrm{ml}\right)$ was mixed 1:1 with 2xRIPA containing no phosphatase or kinase inhibitors, immunoprecipitated using antiSERCA3 (PL/IM430) antibody and purified using the immunoprecipitation kit Dynabead ${ }^{\circledR}$ protein $G$ (Invitrogen, Madrid, Spain). ATPase activity was determined at $37{ }^{\circ} \mathrm{C}$ and $\mathrm{pH} 7.2$, in the absence (4 mM EGTA) and in the presence of $1 \mu \mathrm{M} \mathrm{Ca}^{2+}$ and with and without $10 \mu \mathrm{M}$ TBH added.

\section{Real-time quantitative (RT-PCR)}

Relative expression levels of h-SERCA3d in HEK293T and HeLa cells were assessed by probe-based real-time quantitative RT-PCR (qRT-PCR). Total RNA was extracted with Trizol ${ }^{\mathrm{R}}$ (Invitrogen) and quantified in a NanoDrop apparatus. 1-2 $\mu$ g RNA were reverse transcribed with the High Capacity cDNA Reverse Transcription Kit from Applied Biosystems using MultieScribe-RT and Oligo dT as primers. Amplifications of 1-100 ng cDNA were performed in triplicates using the kit SYBR Green PCR Master Mix in a $25 \mu$ reaction mixture containing $100 \mathrm{nM}$ primers and $100 \mathrm{nM}$ probe (Applied 
Biosystems). Primers were as follows: forward 5'- GAC CAC ACC GGG GCC AGG GAC ACA-3' and reverse 5'- GCC TGT CAT TTA TCC GGC G -3' for h-SERCA3d and forward 5'-TAC CTC CGC TGC ATC TCC -3' and reverse 5' - GCC TGT CAT TTA TCC GGC -3' for RPL18 (housekeeping gene).The PCR was run on an LightCycler 480 (Roche, Germany). Relative gene expression was determined with the $2^{-\Delta \Delta C T}$ method [33].

\section{Statistics}

Data are expressed as mean \pm S.E.M. Statistical significance was evaluated by Student's t-test.

\section{RESULTS}

In order to assess the homogeneity of the calcium pools mobilized by agonists we compared the size of the $\left[\mathrm{Ca}^{2+}\right]_{\mathrm{C}}$ peaks obtained on stimulation after treatment with different inhibitors. Results are summarized in Figure 1. In these experiments $\mathrm{Ca}^{2+}$ mobilization from the intracellular $\mathrm{Ca}^{2+}$ stores was induced by $\mathrm{IP}_{3}$-producing agonists and the size of the Ca pool was inferred from the size of the $\left[\mathrm{Ca}^{2+}\right]_{\mathrm{C}}$ increase. Both, cholinergic and purinergic agonists are known to stimulate PLC in both, HEK [34] and HeLa cells [35]. We found in preliminary experiments (not shown) that maximum releasing effect was best obtained when carbachol (CCh) and ATP were applied together, so that this stimulus was routinely used in further experiments. Figure 1 shows mobilization of the stored $\mathrm{Ca}^{2+}$, visualized as the increase of $\left[\mathrm{Ca}^{2+}\right]_{\mathrm{C}}$, by stimulation with $100 \mu \mathrm{M} \mathrm{CCh}+100 \mu \mathrm{M}$ ATP in HEK (A-D) and HeLa (E-H) cells. Stimulation was performed in $\mathrm{Ca}^{2+}$-free medium to avoid contamination of the $\left[\mathrm{Ca}^{2+}\right]_{\mathrm{C}}$ peak with $\mathrm{Ca}^{2+}$ entry through the plasma membrane. The first peak was triggered $30 \mathrm{~s}$ after removing $\mathrm{Ca}^{2+}$, a period long enough to allow complete washing of the extracellular $\mathrm{Ca}^{2+}$, but short enough to avoid substantial emptying of the intracellular $\mathrm{Ca}^{2+}$ stores (A, E). The second peak was obtained after $12 \mathrm{~min}$ incubation in $\mathrm{Ca}^{2+}$ free medium (B, F). This $\left[\mathrm{Ca}^{2+}\right]_{\mathrm{C}}$ increment was about $80 \%$ of the first one, suggesting that passive emptying of the intracellular $\mathrm{Ca}^{2+}$ stores by removal of external $\mathrm{Ca}^{2+}$ is relatively slow in both HEK and HeLa cells. In another series of experiments, reuptake of $\mathrm{Ca}^{2+}$ into the ER during the incubation in $\mathrm{Ca}^{2+}$-free medium was prevented by adding the SERCA inhibitor TBH [36]. $\left[\mathrm{Ca}^{2+}\right]_{\mathrm{C}}$ increased transiently during the incubation with $\mathrm{TBH}$ in $\mathrm{Ca}^{2+}$-free medium, suggesting that there is a slow $\mathrm{Ca}^{2+}$ release from the stores under these circumstances $(\mathrm{C}, \mathrm{G})$. After $12 \mathrm{~min}$ incubation with TBH in $\mathrm{Ca}^{2+}$ free medium there was a nearly complete emptying of the $\mathrm{IP}_{3}$-sensitive $\mathrm{Ca}^{2+}$ store in HeLa cells, where the $\left[\mathrm{Ca}^{2+}\right]_{\mathrm{C}}$ peak induced by $\mathrm{CCh}+\mathrm{ATP}$ was under $2 \%$ of the control (Figure $1 \mathrm{G}$ ). In contrast, the $\left[\mathrm{Ca}^{2+}\right]_{\mathrm{C}}$ peak obtained in HEK cells by stimulation with $\mathrm{CCh}+\mathrm{ATP}$ after 12 min incubation with TBH in $\mathrm{Ca}^{2+}$-free medium was quite substantial (64\% of the control value; Figure 1C). Treatment with $1 \mu \mathrm{M}$ thapsigargin, another SERCA inhibitor [37], completely prevented responses to CCh+ATP, both in HeLa and in HEK cells (Figure 1D and 1H) indicating that the intracellular $\mathrm{Ca}^{2+}$ stores sensitive to $\mathrm{IP}_{3}$ are completely emptied by treatment with this inhibitor. The same results were obtained with another SERCA inhibitor $[18,38]$ cyclopiazonic acid (CPA; traces not shown). The averaged results of several similar experiments are shown in panels I and $\mathrm{J}$ of Figure 1. To summarize, it seems clear from our results that there is a substantial part of the $\mathrm{IP}_{3}$ sensitive $\mathrm{Ca}^{2+}$ pool of HEK cells that is resistant to TBH, but sensitive to TG or CPA and that this $\mathrm{Ca}^{2+}$ pool does not exist in HeLa cells.

Figure 2 shows that the TBH-resistant $\mathrm{Ca}^{2+}$ pool of HEK cells can be emptied by stimulation with agonists and then filled again by incubation with $\mathrm{Ca}^{2+}$. The cells were treated with TBH in $\mathrm{Ca}^{2+}-$ free medium for $12 \mathrm{~min}$. and then three consecutive pulses of CCh+ATP were applied. The first stimulus produced a large $\left[\mathrm{Ca}^{2+}\right]_{\mathrm{C}}$ peak, the effect of the second one was much smaller and the third response was hardly detectable, indicating that the $\mathrm{Ca}^{2+}$ store was completely empty. On readdition of $\mathrm{Ca}^{2+}$ (in the continuous presence of TBH) $\left[\mathrm{Ca}^{2+}\right]_{\mathrm{C}}$ increased very much and then declined slowly. The first step reflects rapid $\mathrm{Ca}^{2+}$ entry through capacitative mechanisms (store-operated $\mathrm{Ca}^{2+}$ entry, $\mathrm{SOCE}$ ), which are activated by the emptying of the intracellular $\mathrm{Ca}^{2+}$ stores [39]. As the intracellular stores refill, store-operated channels (SOC) deactivate and $\left[\mathrm{Ca}^{2+}\right]_{\mathrm{C}}$ decreases. After 9 min., external $\mathrm{Ca}^{2+}$ was removed again and the cells were stimulated with $\mathrm{CCh}+\mathrm{ATP}$. The stimulus produced a $\mathrm{Ca}^{2+}$ peak that 
was $80 \%$ as high as the initial one, indicating that the TBH-resistant intracellular $\mathrm{Ca}^{2+}$ stores had refilled substantially. The second stimulus had little effect, suggesting that the $\mathrm{Ca}^{2+}$ content of the intracellular stores was almost completely mobilized by the first stimulus.

Accumulation of $\mathrm{Ca}^{2+}$ into acidic [15] or alkaline [40] intracellular compartments has been described in different cell systems. Collapsing the $\mathrm{pH}$ gradient empties these $\mathrm{Ca}^{2+}$ stores and abolishes the release in both cases. Figure 3 shows the results of experiments designed to assess a role of acidic or alkaline intracellular compartments in the accumulation of $\mathrm{Ca}^{2+}$ inside TBH-resistant compartments. HEK cells were treated for 5 min with TBH in $\mathrm{Ca}^{2+}$ free medium and then the effects of several treatments collapsing $\mathrm{pH}$ gradients were studied by following the $\left[\mathrm{Ca}^{2+}\right]_{\mathrm{C}}$ peaks induced by $\mathrm{CCh}+\mathrm{ATP}$. The effects of substances able to change the cytoplasmic $\mathrm{pH}$ should be regarded with some caution as the $\mathrm{pH}$ changes modify also the affinity of the $\mathrm{Ca}^{2+}$ probes and could then disturb the measurements. Here we tested the effect of a weak base, trimethylamine (TMA) (Figure 3B), which would accumulate into acidic compartments and thus collapse the $\mathrm{pH}$ gradient; a weak acid, propionate (Figure 3C), which should accumulate inside alkaline compartments; and the $\mathrm{H}^{+} / \mathrm{K}^{+}$exchanger nigericin, which should collapse both acidic and alkaline $\mathrm{pH}$ gradients (Figure 3D). Even though all the three maneuvers produced some effects on the apparent increase of $\left[\mathrm{Ca}^{2+}\right]_{\mathrm{C}}$ (Figure 3A-D), these were relatively small and similar for all the three inhibitors, suggesting that they are no specifically attributable to collapsing the $\mathrm{pH}$ gradient of a subcellular compartment. Finally, the lysosomal disruptor GPN did not inhibit the $\left[\mathrm{Ca}^{2+}\right]_{\mathrm{C}}$ peak (Figure 3E); as a matter of fact, the height of the peak was usually increased by GPN, the contrary outcome to the expected one if acidic granules contributed to the TBH-resistant agonist-sensitive $\mathrm{Ca}^{2+}$ pool of HEK cells. These results suggest that the TBHresistant store of HEK cells is not (or not only) inside either acidic or alkaline granules.

We investigated directly the implication of the ER as a TBH-resistant store by measuring its $\mathrm{Ca}^{2+}$ content with an ER-targetedd aequorin $[26,41]$. The results of these experiments are shown in Figure 4; erGA-transfected HEK (A) and HeLa cells (B) whose $\mathrm{Ca}^{2+}$ stores had been emptied were allowed to refill with $\mathrm{Ca}^{2+}$, either in control medium with $1 \mathrm{mM} \mathrm{Ca}^{2+}$ (CONT.) or in medium containing $1 \mathrm{mM} \mathrm{Ca}^{2+}$ and $10 \mu \mathrm{M} \mathrm{TBH}(+\mathrm{TBH})$. After 5-min refilling, the cells were stimulated with $\mathrm{CCh}+\mathrm{ATP}$. In the control condition the ER refilled to levels approaching $500 \mu \mathrm{M}$ in both cell types and stimulation with $\mathrm{CCh}+\mathrm{ATP}$ produced $\mathrm{Ca}^{2+}$ release. Emptying was more complete in HeLa than in HEK cells. In the presence of TBH there was hardly any refilling in HeLa cells whereas in HEK cells ER refilled to about $20 \%$ of the control value and $\mathrm{CCh}+\mathrm{ATP}$ produced a near-complete $\mathrm{Ca}^{2+}$ release.

As AEQ is burnt during light emission on $\mathrm{Ca}^{2+}$ binding $[28,42]$ the fractional consumption at equilibrium measures the fraction of the AEQ-containing space that is occupied by $\mathrm{Ca}^{2+}$. Figure 5 compares the time courses of the consumption of the ER-targeted aequorin in HEK and HeLa cells during refilling of the intracellular $\mathrm{Ca}^{2+}$ stores in the presence of TBH $\left(\mathrm{Ca}^{2+}+\mathrm{TBH}\right.$ bar $)$. After $5 \mathrm{~min}$, TBH was removed to allow rapid refilling of the TRH-sensitive stores $\left(\mathrm{Ca}^{2+}\right.$ bar). In HeLa cells burning of AEQ was extremely slow in the presence of TBH and seemed to be circumscribed to a small fraction (about 10\%) of the total AEQ pool. In HEK cells, the AEQ pool that burned in the presence of AEQ was much larger, over $60 \%$ during the 5-min observation period. In order to measure the size of the ER-AEQ pools more precisely, a new series of experiments was designed reconstituting erAEQ with native coelenterazine. Under these conditions the affinity of AEQ for $\mathrm{Ca}^{2+}$ increases and consumption is much faster and more sensitive to smaller $\mathrm{Ca}^{2+}$ concentrations. Results are shown in Figure 6, where the time courses of the consumptions either with $\mathrm{Ca}^{2+}$ alone or in the presence of TBH are compared. In HEK cells (Figure 6A) the consumption was almost complete $(>80 \%)$ in both cases, somewhat slower in the presence of TBH. This suggests that most of the ER pool is able to accumulate $\mathrm{Ca}^{2+}$ even in the presence of TBH. The results in HeLa cells were very different (Figure 6B). Refilling in the presence of TBH (dotted trace) was very slow but, in addition, it seemed to happen into a limited fraction of the total $\mathrm{Ca}^{2+}$ pool amounting less than $20 \%$ of the total aequorin. When TBH was removed the rest of the $\mathrm{Ca}^{2+}$ pool was consumed quickly revealing the presence of the TBH-sensitive $\mathrm{Ca}^{2+}$ pumping mechanism. When $\mathrm{Ca}^{2+}$ was given in the absence of $\mathrm{TBH}$ from the very beginning (continuous trace) erAEQ was consumed quickly and completely.

It has been reported that the expression of SERCA2b by HeLa and HEK cells is similar, but HEK cells express higher SERCA3 levels than HeLa cells [43] and that the major isoform is SERCA3d [43]. We have determined and compared the relative abundance of the SERCA3d isoform in HEK and HeLa cells by quantitative RT-PCR and confirm the differences between both cell types. 
We found that the relative expression of SERCA $3 d$ is (mean \pm S.E.M.; $n=3$ ) $19 \pm 5$ fold higher in HEK cells than in HeLa cells.

In order to investigate whether the differences found in $\mathrm{ER} \mathrm{Ca}^{2+}$ transport between HEK and HeLa cells could be related to differences in the expression of SERCA isoforms, we determined the $\mathrm{Ca}^{2+}$-dependent ATPase activity linked to SERCA3 in HEK and HeLa cells, and compared the sensitivity to TBH. Figure 7 shows the averaged values of ATPase activity obtained with and without $\mathrm{Ca}^{2+}$ and in absence and presence of TBH. The $\mathrm{Ca}^{2+}$-dependent activity was larger in HEK than in HeLa cells, nominally (mean \pm S.E.M) $0.217 \pm 0.023 \mathrm{vs} 0.093 \pm 0.003 \mu \mathrm{mol} \cdot \mathrm{min}^{-1} \cdot \mathrm{mg}$ protein $^{-1}$ (compare panels A and B) $(p<0.001)$. Even more striking was the fact that whereas TBH inhibited completely $(87-99 \%)$ the $\mathrm{Ca}^{2+}$ stimulated ATPase activity in HeLa cells (Figure 7B), there was a substantial fraction (32-46\%) of TBH-resistant activity in HEK cells (Figure 7A).

Finally, we studied the effects of expressing SERCA3d on the TBH-resistant $\mathrm{Ca}^{2+}$ storage in HeLa cells. The results are shown in Figure 8. The $\mathrm{Ca}^{2+}$ content of the intracellular stores was estimated either from the size of the $\left[\mathrm{Ca}^{2+}\right]_{\mathrm{C}}$ peak induced by stimulation with agonists in fura-2loaded HeLa cells (A and B) or by directly measuring the $\mathrm{Ca}^{2+}$ uptake into the ER with targeted aequorin (C and D). As shown above (Figure 1 and Figure 4), HeLa cells did not show any indication of TBH-resistant storage of $\mathrm{Ca}^{2+}$ into the ER: there was not $\left[\mathrm{Ca}^{2+}\right]_{\mathrm{C}}$ increase on stimulation with $\mathrm{ATP}+\mathrm{CCh}$ (Figure 8A) and the ER refilled very little with $\mathrm{Ca}^{2+}$ (below $0.1 \mathrm{mM}$, Figure 8C). In contrast, upon SERCA3d overexpression the release of $\mathrm{Ca}^{2+}$ by stimulation with $\mathrm{CCh}+\mathrm{ATP}$ was sharply increased (Figure 8B) and direct measurement of ER content showed increased refilling (to about 6 fold more than in the control (Figure 8D). Moreover, this stored $\mathrm{Ca}^{2+}$ was completely released by stimulation with $\mathrm{CCh}+\mathrm{ATP}$.

\section{DISCUSSION}

Our results reveal heterogeneity of $\mathrm{Ca}^{2+}$ stores in HEK cells, where a TBH-resistant store was found (Figure 1C). This store was able to sustain the $\mathrm{IP}_{3}$-induced $\left[\mathrm{Ca}^{2+}\right]_{\mathrm{C}}$ peak to values near $80 \%$ of the control (Figure 1I). Both thapsigargin and cyclopiazonic acid were able to empty completely the TBH-resistant $\mathrm{Ca}^{2+}$ store (Figure 1D; Figure 1I). In contrast with HEK cells, HeLa cells did not show evidence for a TBH-resistant Ca store (Figure 1G; Fig1J). In lymphocytes, TBH has also been shown to empty completely the intracellular $\mathrm{Ca}^{2+}$ stores [18]. Once emptied by stimulation with agonists, the TBH-resistant store of HEK cells refilled by incubation with external $\mathrm{Ca}^{2+}$, even in the presence of TBH (Figure 2).

What may be the structural basis that justifies the differences in intracellular $\mathrm{Ca}^{2+}$ storage in the various cell models? In platelets it seems clear that the TBH-sensitive and the TBH-resistant $\mathrm{Ca}^{2+}$ stores correspond to two different $\mathrm{Ca}^{2+}$ pools, located either inside the acidic dense granules and lysosomes or in the dense tubular system, respectively $[9,11,14,15]$. As a consequence, $\mathrm{Ca}^{2+}$ is released from the granules by substances collapsing the $\mathrm{H}^{+}$gradient, such as the $\mathrm{K}^{+} / \mathrm{H}^{+}$exchanger nigericin or the vacuolar $\mathrm{H}^{+}$-ATPase inhibitor bafilomycin, and with the osmotic lysosomal disruptor GPN. In the case of HEK cells these maneuvers did not abolish the TBH-resistant $\mathrm{Ca}^{2+}$ release from the stores (Figure 3 ) suggesting that, in these cells, $\mathrm{Ca}^{2+}$ comes from another store. The effects of substances collapsing acidic and alkaline gradients, such as trimethylamine and propionate (Figure $3 \mathrm{~B}$ and C), were relatively small and similar, suggesting that $\Delta \mathrm{H}^{+}$of the store is not essential for TBHresistant $\mathrm{Ca}^{2+}$ accumulation.

In addition, we have direct evidence showing that the TBH-resistant $\mathrm{Ca}^{2+}$ pool accumulates inside the ER, as revealed by the ER targeted-AEQ (Figure 4B). The $\mathrm{Ca}^{2+}$ concentration attained by the TBH-resistant accumulation mechanism in this pool seemed smaller (about 1/5) than $\left[\mathrm{Ca}^{2+}\right]_{\mathrm{ER}}$ normally reached in the bulk of the store (Figure $4 \mathrm{~A}$ ). Stimulation with the $\mathrm{IP}_{3}$-producing agonists released $\mathrm{Ca}^{2+}$ from the TBH-resistant store as efficiently as or even better than from the bulk ER in HEK cells (Figure4A and B). Consistently with the results obtained with fura-2 (Figure 1) ER-targeted AEQ showed that, in HeLa cells, emptying of ER by TBH was virtually complete and that ER did not refill significantly when incubated with $\mathrm{Ca}^{2+}$ in the presence of TBH (Figure 4B).

Since AEQ is burned out in the presence of $\mathrm{Ca}^{2+}$, the relative AEQ consumption at equilibrium informs us on the size of the $\mathrm{Ca}^{2+}$ pool involved in $\mathrm{Ca}^{2+}$ uptake. Using this strategy we find that the 
relative size of the TBH-resistant $\mathrm{ER} \mathrm{Ca}^{2+}$ pool, as indicated by the asymptotic fraction of AEQ consumption, is very different in HEK and in HeLa cells (Figure 5). The test can be made more sensitive by increasing the affinity of AEQ for $\mathrm{Ca}^{2+}$. We repeated the measurements using native coelenterazine instead of coelenterazine $n$ to increases the affinity of AEQ for $\mathrm{Ca}^{2+}$ [26-28]. This makes consumption much faster and more sensitive to smaller $\mathrm{Ca}^{2+}$ concentrations and allows a more precise and astringent estimation of the TBH-resistant pool. In HEK cells the TBH-resistant AEQ pool was $>80 \%$ of the total pool (Figure 6A) suggesting that there is a communication between the TBHresistant and the TBH-sensitive pools or that the mechanism responsible for $\mathrm{Ca}^{2+}$ uptake distributes along the whole ER. On the contrary, in HeLa cells the TBH-resistant pool, probably overestimated by using an AEQ-coelenterazine system with higher-affinity for $\mathrm{Ca}^{2+}$, amounted only 10-20\% (Figure $6 \mathrm{~B})$.

In platelets, the TBH-sensitive uptake of $\mathrm{Ca}^{2+}$ into the acidic granules seems to be related with a distinct SERCA isoform [9], which has been later identified as SERCA3 [10], present also in several other tissues $[19,44]$. On the other hand, SERCA2b would be resistant to TBH in platelets $[9,10]$. However SERCA2b (as well as and SERCA1) activity and ER $\mathrm{Ca}^{2+}$ uptake have been consistently reported to be sensitive to TBH in other tissues, including skeletal muscle, heart, smooth muscle, and lymphocytes [17-20, 45, 46]. The dominant SERCA isoform in HEK and HeLa cells is the 2b [43], which according to our results is sensitive to TBH (Figure 4). It has been reported that HEK, but not HeLa cells, express, in addition a SERCA3d isoform [43] and we confirm it here by quantitative RTPCR. In addition, HEK but not HeLa cells showed TBH-resistant SERCA3-mediated ATPase activity (Figure 7). Finally, overexpresion of SERCA3d in HeLa cells generated a TBH-resistant intracellular $\mathrm{Ca}^{2+}$ pool in the ER (Figure 8D), which was released by stimulation with $\mathrm{IP}_{3}$-producing agonists. These results suggest that SERCA3d may be responsible for the TBH-resistant $\mathrm{Ca}^{2+}$ pool of HEK cells and opens the question on whether differential expression of SERCA isoforms [44] could modify the properties of intracellular calcium stores and to allow coexistence of different pools, perhaps fulfilling different functions, in the same cell.

The presence of two distinct ER-derived $\mathrm{Ca}^{2+}$ compartments in HEK cells might have functional relevance as described in other cells, where function-specific $\mathrm{Ca}^{2+}$ compartments have been reported to regulate different cellular functions by multiple agonists. For instance, in human platelets the TBH-sensitive acidic store is discharged upon occupation of high-affinity thrombin receptors and participates in aggregation [14, 47]. Similarly, in goldfish somatotropes, two different $\mathrm{Ca}^{2+}$ stores may differentially regulate growth hormone storage and secretion [48]. Therefore, our findings further advance our understanding of organellar $\mathrm{Ca}^{2+}$ stores underlying the generation of differential $\mathrm{Ca}^{2+}$ signals by different $\mathrm{Ca}^{2+}$-mobilizing agonists.

\section{AUTHOR CONTRIBUTION}

Francisco J. Aulestia, Pedro C. Redondo and Arancha Rodríguez-García , performed most of the experiments. Juan A. Rosado, Ginés M. Salido, Maria Teresa Alonso and Javier-García-Sancho provided conceptual input and designed the experiments. All authors participated in analysis, discussion and interpretation of data, revised the article, and gave final approval.. Javier García-Sancho put together all data and wrote the final form of the manuscript.

\section{ACKNOWLEDGEMENTS}

We are grateful to Dr. Jocelyne Enouf, Inserm, U 689, Paris, for the human SERCA 3d cDNA. We thank Carmen Galán for assistance in some experiments and Jesús Fernández and Miriam García Cubillas for technical help.

\section{FUNDING}

This work was supported by grants from The Spanish Ministerio de Ciencia e Innovación [MICINN-FEDER BFU2007-60157, BFU2007-60104 and RD06/0010/0000] and the Junta de Castilla y León [GR175]. Francisco J Aulestia was supported by a fellowship from the Spanish MICINN. 


\section{REFERENCES}

1 Clapham, D. E. (2007) Calcium signaling. Cell. 131, 1047-1058

2 Lissandron, V., Podini, P., Pizzo, P. and Pozzan, T. (2010) Unique characteristics of Ca2+ homeostasis of the trans-Golgi compartment. Proc Natl Acad Sci U S A. 107, 9198-9203

3 Galione, A. (2006) NAADP, a new intracellular messenger that mobilizes $\mathrm{Ca} 2+$ from acidic stores. Biochem Soc Trans. 34, 922-926

4 Galione, A., Evans, A. M., Ma, J., Parrington, J., Arredouani, A., Cheng, X. and Zhu, M. X. (2009) The acid test: the discovery of two-pore channels (TPCs) as NAADP-gated endolysosomal $\mathrm{Ca}(2+)$ release channels. Pflugers Arch. 458, 869-876

5 Patel, S., Marchant, J. S. and Brailoiu, E. (2010) Two-pore channels: Regulation by NAADP and customized roles in triggering calcium signals. Cell Calcium. 47, 480-490

6 Gerasimenko, J. V., Sherwood, M., Tepikin, A. V., Petersen, O. H. and Gerasimenko, O. V. (2006) NAADP, cADPR and IP3 all release Ca2+ from the endoplasmic reticulum and an acidic store in the secretory granule area. J Cell Sci. 119, 226-238

7 Petersen, O. H. and Tepikin, A. V. (2008) Polarized calcium signaling in exocrine gland cells. Annu Rev Physiol. 70, 273-299

8 Yoo, S. H. (2009) Secretory granules in inositol 1,4,5-trisphosphate-dependent Ca2+ signaling in the cytoplasm of neuroendocrine cells. FASEB J. 24, 653-664

9 Papp, B., Enyedi, A., Paszty, K., Kovacs, T., Sarkadi, B., Gardos, G., Magnier, C., Wuytack, F. and Enouf, J. (1992) Simultaneous presence of two distinct endoplasmic-reticulum-type calciumpump isoforms in human cells. Characterization by radio-immunoblotting and inhibition by 2,5-di(t-butyl)-1,4-benzohydroquinone. Biochem J. 288 ( Pt 1), 297-302

10 Wuytack, F., Papp, B., Verboomen, H., Raeymaekers, L., Dode, L., Bobe, R., Enouf, J., Bokkala, S., Authi, K. S. and Casteels, R. (1994) A sarco/endoplasmic reticulum Ca(2+)-ATPase 3-type $\mathrm{Ca} 2+$ pump is expressed in platelets, in lymphoid cells, and in mast cells. J Biol Chem. 269, 14101416

11 Cavallini, L., Coassin, M. and Alexandre, A. (1995) Two classes of agonist-sensitive Ca2+ stores in platelets, as identified by their differential sensitivity to 2,5-di-(tert-butyl)-1,4benzohydroquinone and thapsigargin. Biochem J. 310 ( Pt 2), 449-452

12 Juska, A., Jardin, I. and Rosado, J. A. (2008) Physical properties of two types of calcium stores and SERCAs in human platelets. Mol Cell Biochem. 311, 9-18

13 Lopez, J. J., Redondo, P. C., Salido, G. M., Pariente, J. A. and Rosado, J. A. (2006) Two distinct $\mathrm{Ca} 2+$ compartments show differential sensitivity to thrombin, ADP and vasopressin in human platelets. Cell Signal. 18, 373-381

14 Jardin, I., Ben Amor, N., Bartegi, A., Pariente, J. A., Salido, G. M. and Rosado, J. A. (2007) Differential involvement of thrombin receptors in $\mathrm{Ca} 2+$ release from two different intracellular stores in human platelets. Biochem J. 401, 167-174

15 Lopez, J. J., Camello-Almaraz, C., Pariente, J. A., Salido, G. M. and Rosado, J. A. (2005) Ca2+ accumulation into acidic organelles mediated by $\mathrm{Ca} 2+-$ and vacuolar $\mathrm{H}+-\mathrm{ATPases}$ in human platelets. Biochem J. 390, 243-252

16 Periasamy, M. and Kalyanasundaram, A. (2007) SERCA pump isoforms: their role in calcium transport and disease. Muscle Nerve. 35, 430-442

17 Lape, M., Elam, C., Versluis, M., Kempton, R. and Paula, S. (2008) Molecular determinants of sarco/endoplasmic reticulum calcium ATPase inhibition by hydroquinone-based compounds. Proteins. 70, 639-649

18 Mason, M. J., Garcia-Rodriguez, C. and Grinstein, S. (1991) Coupling between intracellular Ca2+ stores and the $\mathrm{Ca} 2+$ permeability of the plasma membrane. Comparison of the effects of thapsigargin, 2,5-di-(tert-butyl)-1,4-hydroquinone, and cyclopiazonic acid in rat thymic lymphocytes. J Biol Chem. 266, 20856-20862

19 Vangheluwe, P., Sepulveda, M. R., Missiaen, L., Raeymaekers, L., Wuytack, F. and Vanoevelen, J. (2009) Intracellular Ca2+- and Mn2+-transport ATPases. Chem Rev. 109, 4733-4759

20 Wootton, L. L. and Michelangeli, F. (2006) The effects of the phenylalanine 256 to valine mutation on the sensitivity of sarcoplasmic/endoplasmic reticulum Ca2+ ATPase (SERCA) Ca2+ pump isoforms 1, 2, and 3 to thapsigargin and other inhibitors. J Biol Chem. 281, 6970-6976 
21 Pinton, P., Pozzan, T. and Rizzuto, R. (1998) The Golgi apparatus is an inositol 1,4,5trisphosphate-sensitive $\mathrm{Ca} 2+$ store, with functional properties distinct from those of the endoplasmic reticulum. EMBO J. 17, 5298-5308

22 Ong, H. L., Liu, X., Tsaneva-Atanasova, K., Singh, B. B., Bandyopadhyay, B. C., Swaim, W. D., Russell, J. T., Hegde, R. S., Sherman, A. and Ambudkar, I. S. (2007) Relocalization of STIM1 for activation of store-operated $\mathrm{Ca}(2+)$ entry is determined by the depletion of subplasma membrane endoplasmic reticulum $\mathrm{Ca}(2+)$ store. J Biol Chem. 282, 12176-12185

23 Nunez, L., De La Fuente, M. T., Garcia, A. G. and Garcia-Sancho, J. (1995) Differential Ca2+ responses of adrenergic and noradrenergic chromaffin cells to various secretagogues. Am J Physiol. 269, C1540-1546

24 Villalobos, C., Nunez, L., Montero, M., Garcia, A. G., Alonso, M. T., Chamero, P., Alvarez, J. and Garcia-Sancho, J. (2002) Redistribution of Ca2+ among cytosol and organella during stimulation of bovine chromaffin cells. FASEB J. 16, 343-353

25 Chamero, P., Manjarres, I. M., Garcia-Verdugo, J. M., Villalobos, C., Alonso, M. T. and GarciaSancho, J. (2008) Nuclear calcium signaling by inositol trisphosphate in GH3 pituitary cells. Cell Calcium. 43, 205-214

26 Alonso, M. T., Barrero, M. J., Michelena, P., Carnicero, E., Cuchillo, I., Garcia, A. G., GarciaSancho, J., Montero, M. and Alvarez, J. (1999) Ca2+-induced Ca2+ release in chromaffin cells seen from inside the ER with targeted aequorin. J Cell Biol. 144, 241-254

27 Barrero, M. J., Montero, M. and Alvarez, J. (1997) Dynamics of [Ca2+] in the endoplasmic reticulum and cytoplasm of intact HeLa cells. A comparative study. J Biol Chem. 272, 2769427699

28 Shimomura, O., Musicki, B., Kishi, Y. and Inouye, S. (1993) Light-emitting properties of recombinant semi-synthetic aequorins and recombinant fluorescein-conjugated aequorin for measuring cellular calcium. Cell Calcium. 14, 373-378

29 Manjarres, I. M., Chamero, P., Domingo, B., Molina, F., Llopis, J., Alonso, M. T. and GarciaSancho, J. (2008) Red and green aequorins for simultaneous monitoring of $\mathrm{Ca} 2+$ signals from two different organelles. Pflugers Arch. 455, 961-970

30 Montero, M., Alonso, M. T., Carnicero, E., Cuchillo-Ibanez, I., Albillos, A., Garcia, A. G., Garcia-Sancho, J. and Alvarez, J. (2000) Chromaffin-cell stimulation triggers fast millimolar mitochondrial $\mathrm{Ca} 2+$ transients that modulate secretion. Nat Cell Biol. 2, 57-61

31 Chandrasekera, C. P. and Lytton, J. (2003) Inhibition of human SERCA3 by PL/IM430. Molecular analysis of the interaction. J Biol Chem. 278, 12482-12488

32 Munch, G., Bolck, B., Karczewski, P. and Schwinger, R. H. (2002) Evidence for calcineurinmediated regulation of SERCA 2a activity in human myocardium. J Mol Cell Cardiol. 34, 321-334

33 Livak, K. J. and Schmittgen, T. D. (2001) Analysis of relative gene expression data using realtime quantitative PCR and the 2(-Delta Delta C(T)) Method. Methods. 25, 402-408

34 Short, A. D., Winston, G. P. and Taylor, C. W. (2000) Different receptors use inositol trisphosphate to mobilize $\mathrm{Ca}(2+)$ from different intracellular pools. Biochem J. 351 Pt 3, 683-686

35 Smit, M. J., Leurs, R., Bloemers, S. M., Tertoolen, L. G., Bast, A., De Laat, S. W. and Timmerman, H. (1993) Extracellular ATP elevates cytoplasmatic free $\mathrm{Ca} 2+$ in HeLa cells by the interaction with a 5'-nucleotide receptor. Eur J Pharmacol. 247, 223-226

36 Moore, G. A., Kass, G. E., Duddy, S. K., Farrell, G. C., Llopis, J. and Orrenius, S. (1990) 2,5Di(tert-butyl)-1,4-benzohydroquinone--a novel mobilizer of the inositol 1,4,5-trisphosphatesensitive Ca2+ pool. Free Radic Res Commun. 8, 337-345

37 Thastrup, O., Dawson, A. P., Scharff, O., Foder, B., Cullen, P. J., Drobak, B. K., Bjerrum, P. J., Christensen, S. B. and Hanley, M. R. (1989) Thapsigargin, a novel molecular probe for studying intracellular calcium release and storage. Agents Actions. 27, 17-23

38 Seidler, N. W., Jona, I., Vegh, M. and Martonosi, A. (1989) Cyclopiazonic acid is a specific inhibitor of the Ca2+-ATPase of sarcoplasmic reticulum. J Biol Chem. 264, 17816-17823

39 Parekh, A. B. and Putney, J. W., Jr. (2005) Store-operated calcium channels. Physiological reviews. 85, 757-810

40 Fonteriz, R. I., Sanchez, A., Mollinedo, F., Collado-Escobar, D. and Garcia-Sancho, J. (1991) The role of intracellular acidification in calcium mobilization in human neutrophils. Biochim Biophys Acta. 1093, 1-6 
41 Montero, M., Brini, M., Marsault, R., Alvarez, J., Sitia, R., Pozzan, T. and Rizzuto, R. (1995) Monitoring dynamic changes in free $\mathrm{Ca} 2+$ concentration in the endoplasmic reticulum of intact cells. EMBO J. 14, 5467-5475

42 Shimomura, O., Johnson, F. H. and Morise, H. (1974) Mechanism of the luminescent intramolecular reaction of aequorin. Biochemistry. 13, 3278-3286

43 Martin, V., Bredoux, R., Corvazier, E., Van Gorp, R., Kovacs, T., Gelebart, P. and Enouf, J. (2002) Three novel sarco/endoplasmic reticulum Ca2+-ATPase (SERCA) 3 isoforms. Expression, regulation, and function of the membranes of the SERCA3 family. J Biol Chem. 277, 2444224452

44 Hadri, L., Pavoine, C., Lipskaia, L., Yacoubi, S. and Lompre, A. M. (2006) Transcription of the sarcoplasmic/endoplasmic reticulum Ca2+-ATPase type 3 gene, ATP2A3, is regulated by the calcineurin/NFAT pathway in endothelial cells. Biochem J. 394, 27-33

45 Kabbara, A. A. and Stephenson, D. G. (1997) Effects of 2,5-di-tert-butylhydroquinone on rat cardiac muscle contractility. Am J Physiol. 272, H1001-1010

46 Luo, D., Nakazawa, M., Yoshida, Y., Cai, J. and Imai, S. (2000) Effects of three different Ca(2+) pump ATPase inhibitors on evoked contractions in rabbit aorta and activities of $\mathrm{Ca}(2+)$ pump ATPases in porcine aorta. Gen Pharmacol. 34, 211-220

47 Ben Amor, N. B., Zbidi, H., Bouaziz, A., Isaac, J., Hernandez-Cruz, J. M., Salido, G. M., Rosado, J. A. and Bartegi, A. (2009) Acidic-store depletion is required for human platelet aggregation. Blood Coagul Fibrinolysis. 20, 511-516

48 Johnson, J. D., Klausen, C., Habibi, H. R. and Chang, J. P. (2002) Function-specific calcium stores selectively regulate growth hormone secretion, storage, and mRNA level. Am J Physiol Endocrinol Metab. 282, E810-819

\section{FIGURE LEGENDS}

Figure 1. Comparison of calcium mobilization from the intracellular calcium stores in HEK293T (A-D) and HeLa cells (E-H). Measurements were performed with fura-2. $\mathrm{Ca}^{2+}$ was removed as indicated by the bars (EGTA) and $10 \mu \mathrm{M}$ TBH or $1 \mu \mathrm{M}$ thapsigargin was added as shown. The $\mathrm{CCh}+\mathrm{ATP}$ bars indicate stimulation with $\mathrm{Ca}^{2+}$-free solution containing $100 \mu \mathrm{M}$ of each agonist. Each trace is the average of 3 similar experiments. Values are expressed as the ratio of the fluorescences excited at 340 and $380 \mathrm{~nm}$. Note calibration in $\left[\mathrm{Ca}^{2+}\right]_{\mathrm{C}}$ at right. Panels $\mathbf{I}$ (HEK cells) and $\mathbf{J}(\mathrm{HeLa}$ cells $)$ show mean \pm S.E.M. $(n=3-6)$ values of the $\left[\mathrm{Ca}^{2+}\right]_{\mathrm{C}}$ peaks obtained in different conditions, as shown in the abscissa axis: Control $\left(\mathrm{Ca}^{2+}\right.$ removal $30 \mathrm{~s}$ before the stimulus); EGTA ( $\mathrm{Ca}^{2+}$ removal 12 min before the stimulus); TBH (12 min. treatment with $10 \mu \mathrm{M} \mathrm{TBH} \mathrm{in} \mathrm{Ca}^{2+}$-free medium before the stimulus); Thapsi. (12 min. treatment with $1 \mu \mathrm{M}$ thapsigargin in $\mathrm{Ca}^{2+}$-free medium before the stimulus); CPA (12 min. treatment with $15 \mu \mathrm{M}$ cyclopiazonic acid in $\mathrm{Ca}^{2+}$-free medium before the stimulus). TBH + S3d, TBH condition in Hela cells overexpressing SERCA3d (See Experimental Procedures and Figure 8).

Figure 2. Emptying and refilling of the TBH-resistant intracellular calcium store of HEK cells. Experiment representative of three similar ones. Other details as in Figure 1.

Figure 3. Effects of several treatments for disrupting $\mathrm{pH}$ gradients in endomembranes on the TBH-resistant intracellular calcium store of HEK cells. TMA, $6 \mathrm{mM}$ trimethylamine; PROP., 6 $\mathrm{mM}$ sodium propionate; NIGER., $10 \mu \mathrm{M}$ nigericin ; GPN, $10 \mu \mathrm{M}$ GPN. Each trace is the average of 36 experiments. Other details as in Figure 1.

Figure 4. Comparison of the $\mathrm{Ca}^{2+}$ refilling and the agonist-induced emptying of ER in HEK (A) and HeLa (B) cells. Cells transfected with erGA and reconstituted with $1 \mu \mathrm{M}$ coelenterazine $\mathrm{n}$ (see Experimental Procedures) were washed with Ca-free medium and, at the time shown, perfused with standard medium containing $1 \mathrm{mM} \mathrm{Ca}^{2+}$ with (CONT., dotted line) or without (+TBH, continous line) $10 \mu \mathrm{M} \mathrm{TBH}$. At the time shown the cells were challenged with carbachol + ATP $(100 \mu \mathrm{M}$ of each one). Values are plotted as $\mathrm{L} / \mathrm{L}_{\text {TOTAL}}$. Calibration in $\left[\mathrm{Ca}^{2+}\right]$ is shown at right. Every trace is the mean of 
3 individual experiments. The values attained at the steady state were (in $\mathrm{L} / \mathrm{L}_{\mathrm{TOTAL}} \cdot 10^{3}$; Control vs TBH; mean \pm S.E.M.): $9.0 \pm 0.4$ vs $1.5 \pm 0.5$ in HEK cells and $7.7 \pm 0.9$ vs $0.2 \pm 0.1$ in HeLa cells. The values for the decrease induced by stimulation with $\mathrm{CCh}+\mathrm{ATP}$ were (in $\Delta \mathrm{L} / \mathrm{L}_{\mathrm{TOTAL}} \cdot 10^{3}$; Control vs $\mathrm{TBH}$; mean \pm S.E.M.): $4.3 \pm 0.1$ vs $1.3 \pm 0.2$ in HEK cells and $7.7 \pm 0.9$ vs non-measurable in HeLa cells.

Figure 5. Comparison of the aequorin consumption in HEK (dotted trace) and in HeLa cells (continous trace) on filling the TRH-resistant calcium stores. Cells treated as in Figure 4 were washed with $\mathrm{Ca}$-free medium and then incubated first with standard medium containing $1 \mathrm{mM} \mathrm{Ca}^{2+}$ and $10 \mu \mathrm{M}$ TBH $\left(\mathrm{Ca}^{2+}+\mathrm{TBH}\right)$ and later with the same medium without $\mathrm{TBH}\left(\mathrm{Ca}^{2+}\right)$. Results are expressed as percent of the total aequorin remaining in the cells at a given time. Each trace is the average of three experiments.

Figure 6. Comparison of the aequorin consumption in HEK (A) and in HeLa cells (B) on filling the intracellular calcium stores in the presence or in the absence of TBH Cells treated as in Figure 4 except that aequorin was reconstituted with native coelenterazine instead of coelenterazine $\mathrm{n}$. This increases the affinity for $\mathrm{Ca}^{2+}$ about one order of magnitude [26, 27, 30]. After 2-min washing with $\mathrm{Ca}^{2+}$-free medium, $1 \mathrm{mM} \mathrm{Ca}^{2+}$ was added, as shown. Results expressed as percent of the total aequorin remaining in the cells at a given time. Each trace is the average of three experiments. In the case of HeLa cells refilled in the presence of TBH the effect of TBH removal is shown at the end of the trace.

Figure 7. SERCA3 ATPase activity in HEK (A) and in HeLa cells (B). Cell extracts were purified by immunoprecipitation and ATPase activity determined by an enzyme-coupled assay (see Experimental Procedures). The values in the absence (EGTA) and in the presence of $1 \mu \mathrm{M} \mathrm{Ca}{ }^{2+}$ $\left(+\mathrm{Ca}^{2+}\right)$, and in the absence (open bars) and in the presence of TBH (black bars) are shown. Each value is the mean \pm S.E.M. of 4 individual data. The values obtained with $20 \mu \mathrm{M}$ TBH (not shown for clarity) were the same as with $10 \mu \mathrm{M} \mathrm{TBH}$.

Figure 8. Expression of SERCA3d generates a TBH-resistant intracellular calcium store in HeLa cells. SERCA3d was cotransfected together with erGA at a 3:1 ratio ; controls were transfected with the empty vector (pcDNA3). A and B, experiments with fura-2-loaded cells. Details as in Figure 1. The sizes of the $\mathrm{Ca}^{2+}$ peaks (in $\Delta$ Ratio $\left.340 / 380\right)$ were (mean \pm s.e.m): control, $0.000 \pm 0.030(\mathrm{n}=3$ ); $+\mathrm{S} 3 \mathrm{~b}, 0.042 \pm 0.020(\mathrm{n}=9)$. C. and D. Aequorin measurements. Details as in Figure 4. Each trace is the average of 4 experiments. The $\left[\mathrm{Ca}^{2+}\right]_{\mathrm{ER}}$ levels reached as the steady state were (in $\mathrm{L} / \mathrm{L}_{\mathrm{TOTAL}} \cdot 10^{3}$; mean \pm S.E.M.): Control 0.4 $\pm 0.2 ; \mathrm{S} 3 \mathrm{~d}, 2.4 \pm 0.2$. 
FIG. 1
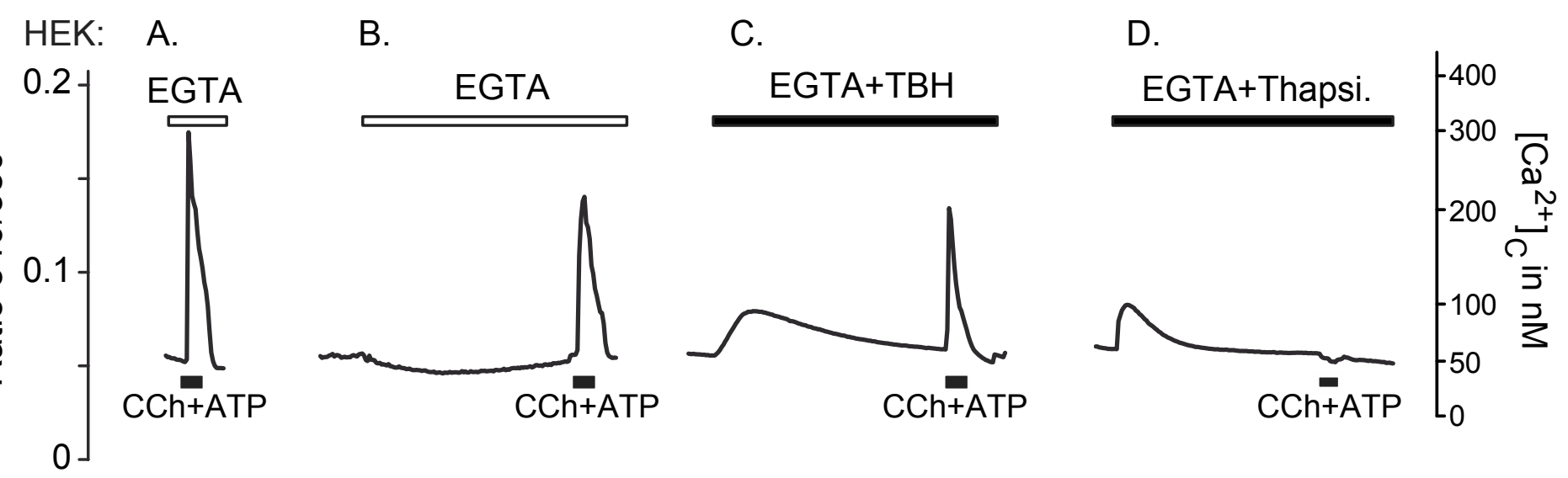

5 min.

HeLa: E.

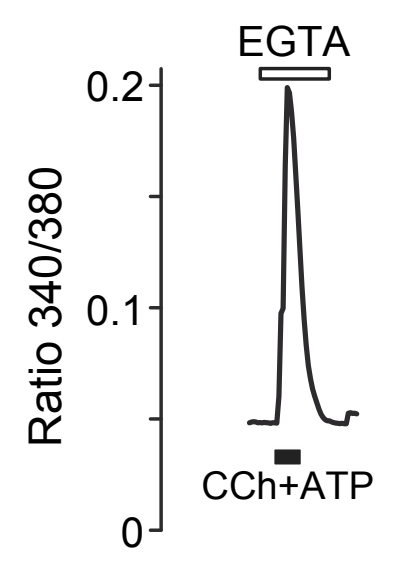

F.

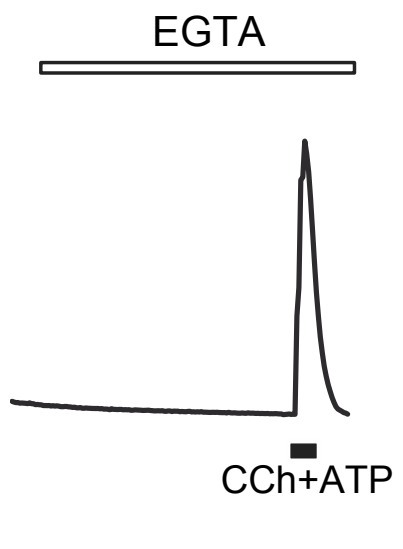

G.

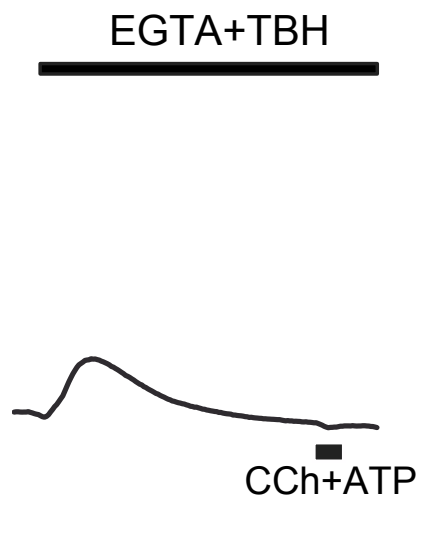

$\mathrm{H}$.

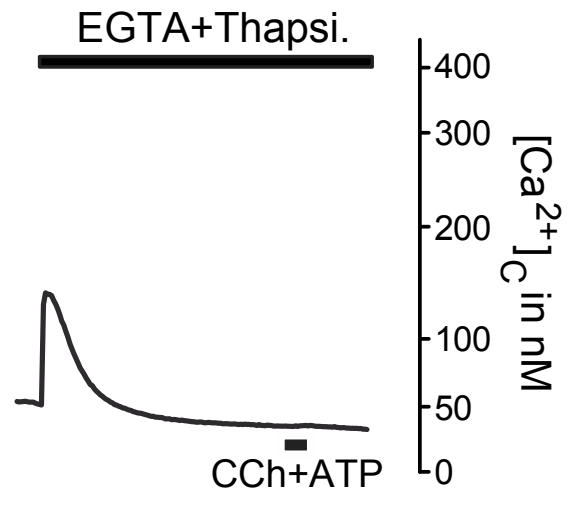

I. HEK

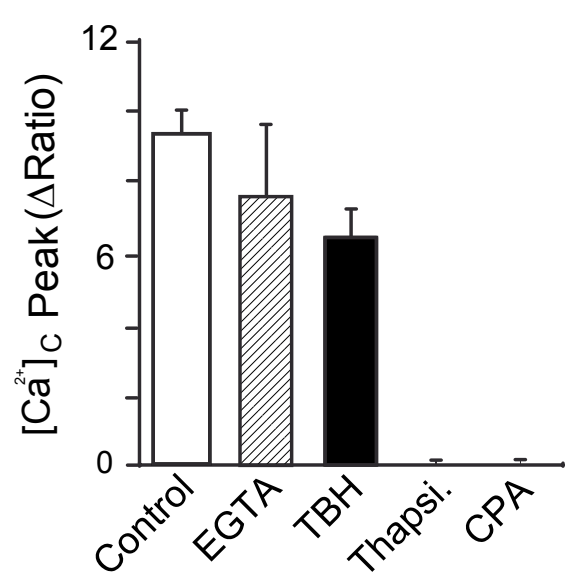

J. HeLa

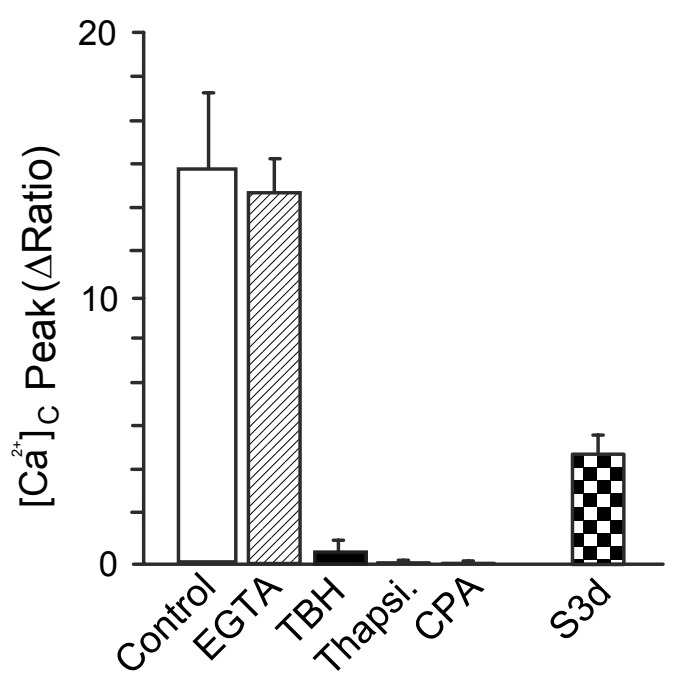


FIG. 2

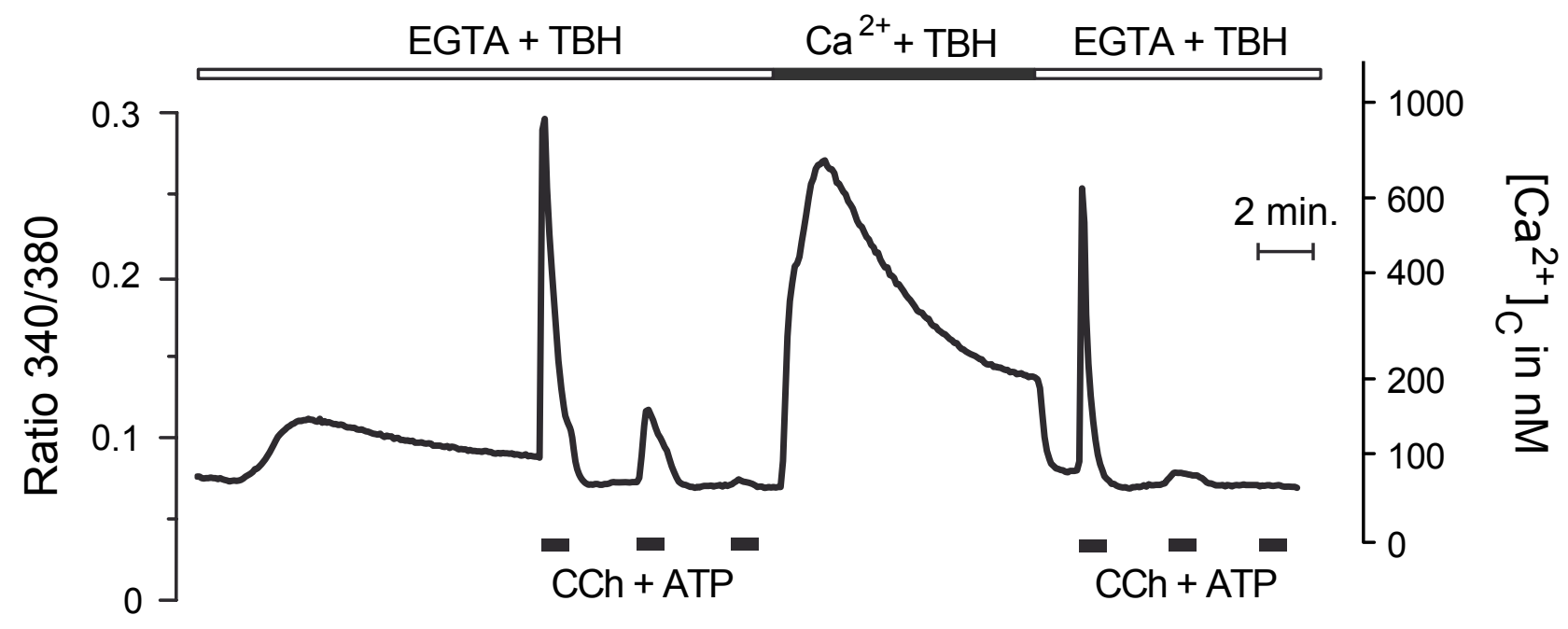


FIG. 3

A.

B.

C.

D.

E.

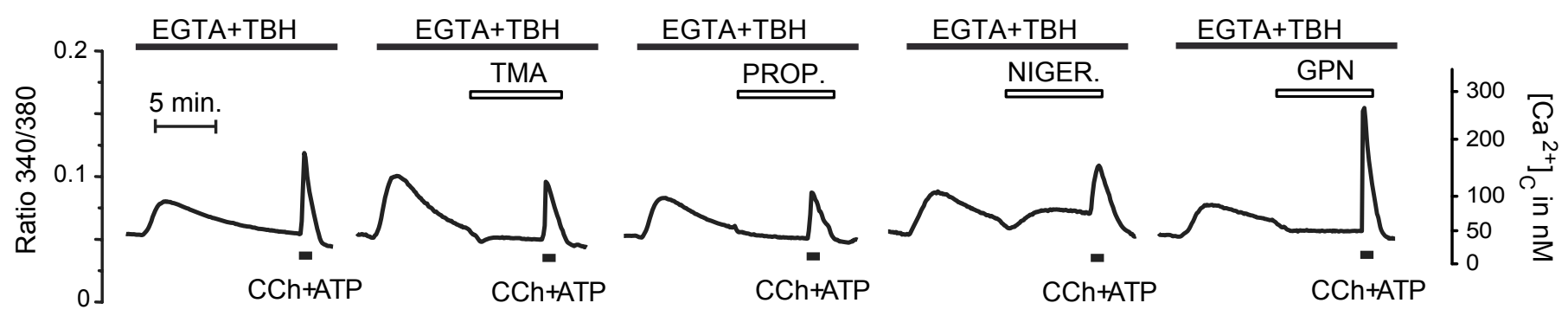


FIG. 4
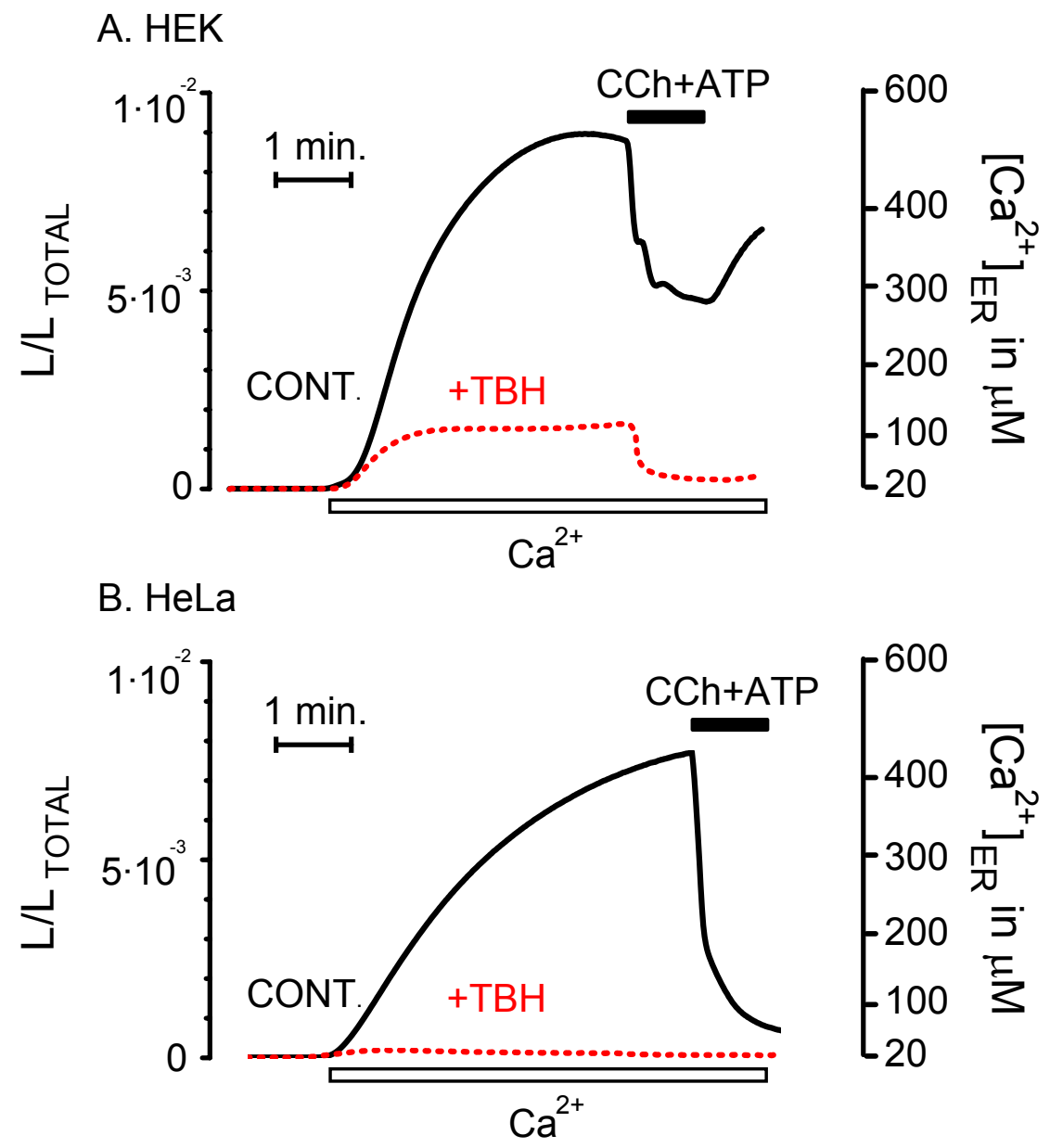
Fig. 5

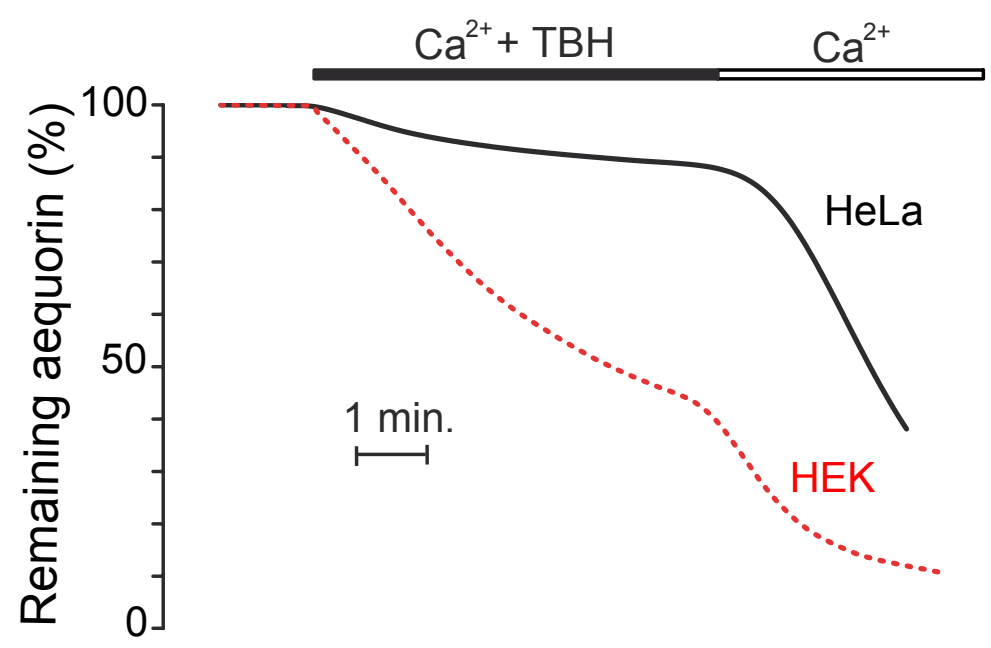


Fig.6

A. HEK

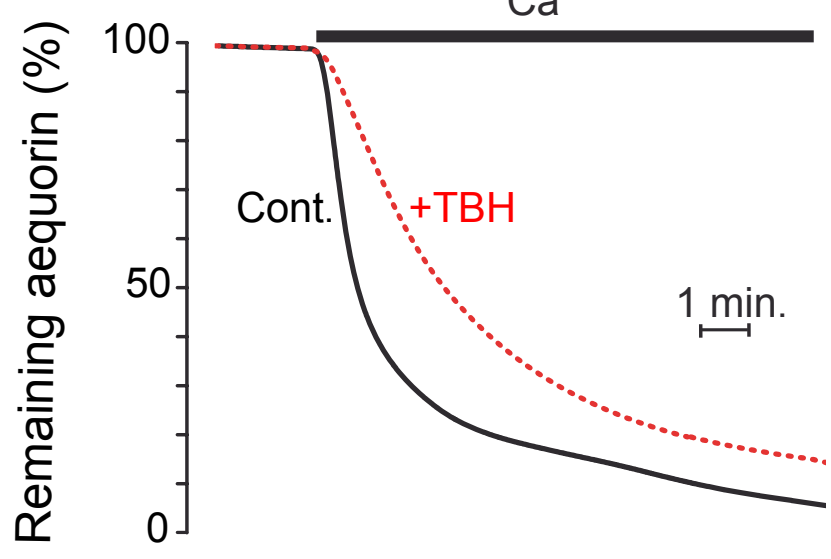

B. HeLa

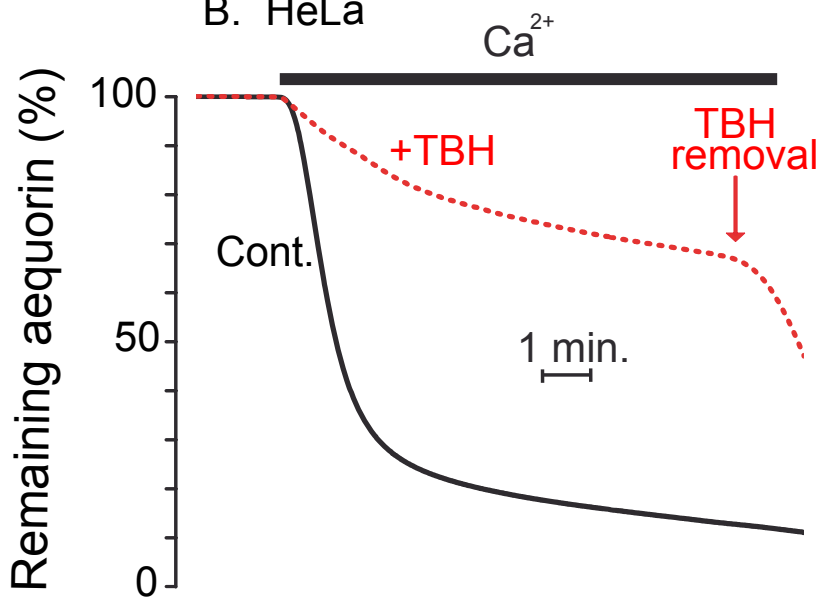


Fig. 7

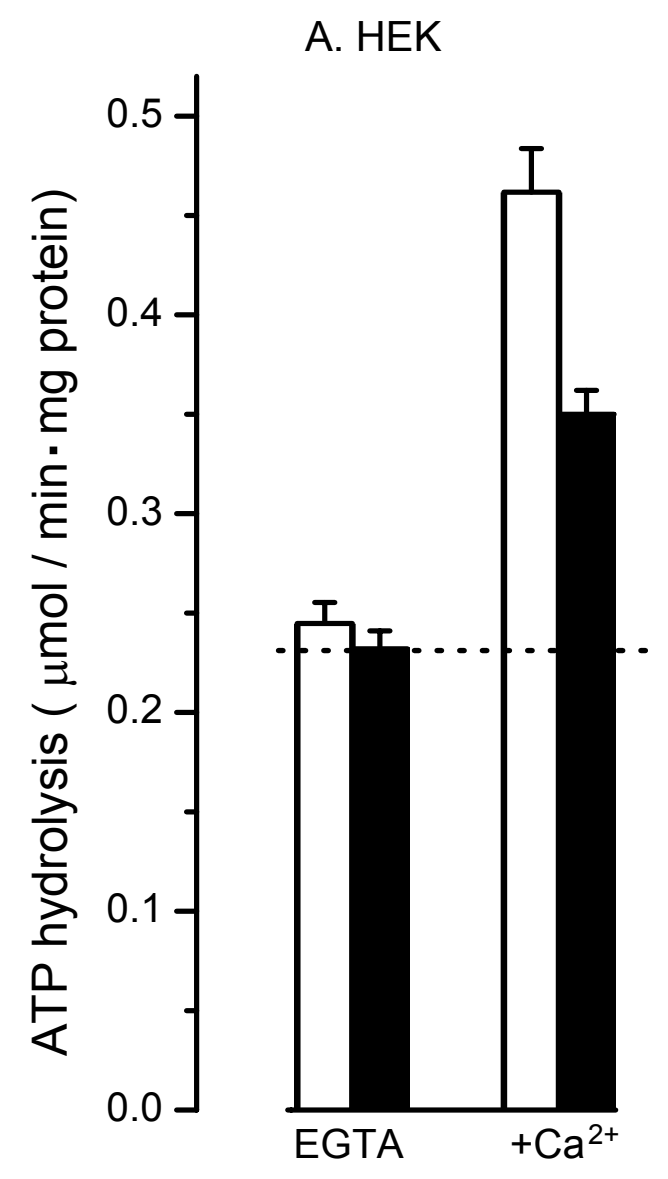

B. HeLa
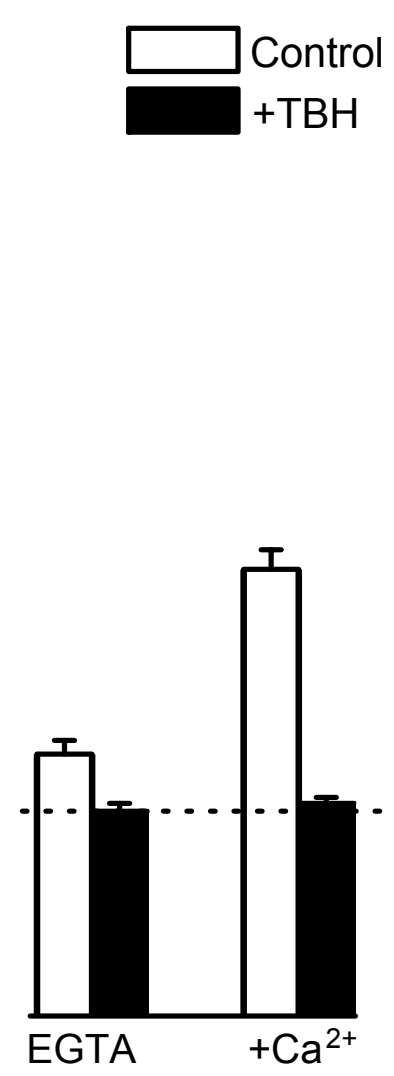
FIG. 8
A. CONTROL
B. $+S 3 d$
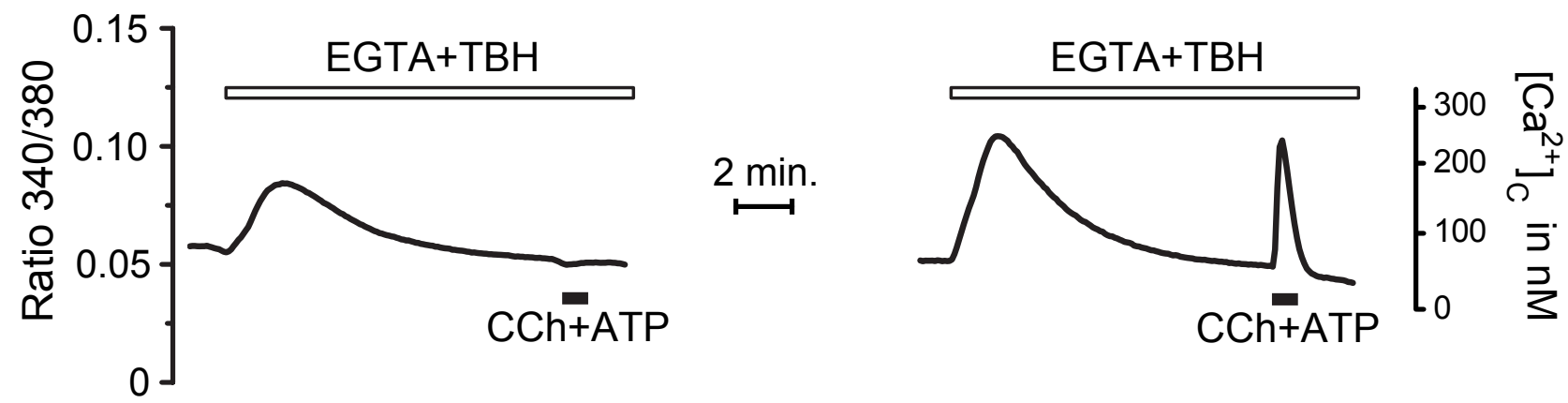

C. CONTROL

D. + S3d
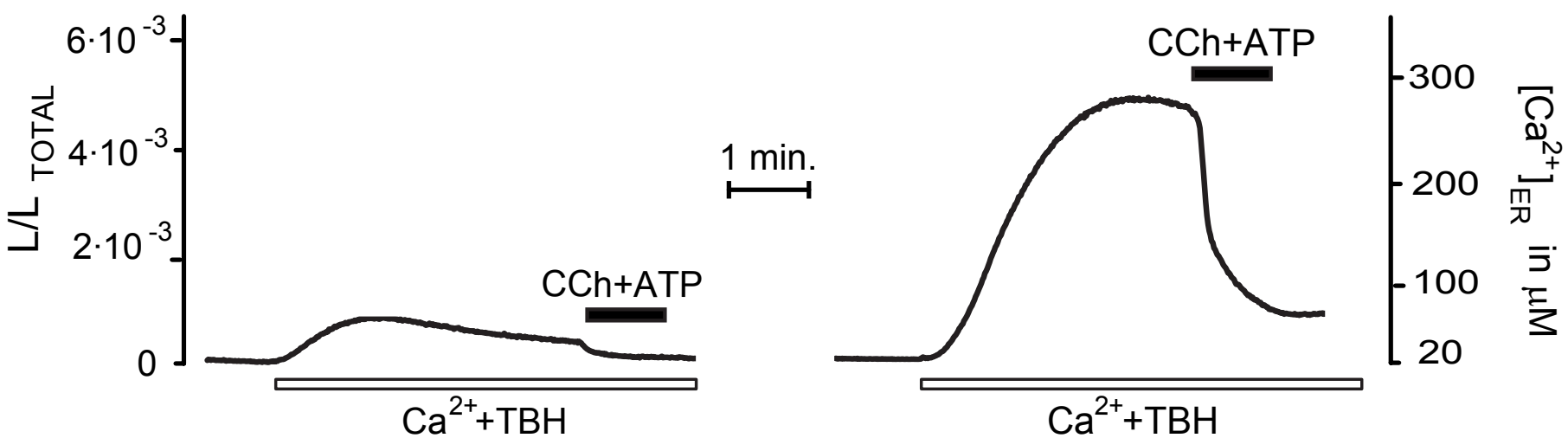